\title{
Karakterisasi Morfologi dan Komponen Hasil Cabai Rawit (Capsicum frutescens L.) Asal Pulau Timor
}

\section{Maria Afnita Lelang ${ }^{\mathrm{a}}$, Syprianus Ceunfin ${ }^{\mathrm{b}}$, dan Adrianus Lelang ${ }^{\mathrm{c}}$}

${ }^{a}$ Fakultas Pertanian, Universitas Timor, Kefamenanu, TTU - NTT, 85613, Indonesia, email: afnitalelang@ymail.com

${ }^{\mathrm{b}}$ Fakultas Pertanian, Universitas Timor, Kefamenanu, TTU - NTT, 85613, Indonesia, email: ceunfins82@ gmail.com

${ }^{\mathrm{c}}$ Fakultas Pertanian, Universitas Timor, Kefamenanu, TTU - NTT, 85613, Indonesia, email: adhylelang@ gmail.com

\section{Article Info}

Article history:

Received 28 Desember 2018

Received in revised form 15 Januari 2019

Accepted 23 Januari 2019

DOI:

https://doi.org/10.32938/sc.v4i01.588

Keywords:

Habitus

Kaliks

Karakterisasi

Morfologi

Plasma nutfah

\begin{abstract}
Abstrak
Cabai rawit merupakan salah satu plasma nutfah asal pulau Timor dikenal dengan sebutan un makaos, un lili, un fua melu atau un ana. Cabai rawit Timor memiliki kekhasan bentuk yakni berukuran kecil dengan panjang berkisar $0,5-2 \mathrm{~cm}$ dan rasa yang sangat pedas. Tujuan dari penelitian ini untuk mengidentifikasi karakter morfologi dan komponen hasil un makaos. Metode penelitian dilakukan berdasarkan kerangka ketentuan UPOV (International Union for The Protection of New Varieties of Plants) dan standar yang ditetapkan oleh IPGR (International Plant Genetic Resources Institute). Hasil penelitian menunjukkan bahwa karakterisasi morfologi cabai rawit pulau Timor teridentifikasi memiliki habitus tanaman dengan percabangan yang kompak, bentuk batang silindris, pemendekan ruas lebih dari tiga dan memiliki batang berwarna hijau. Daun cabai berbentuk ovate (bentuk bulat telur, bagian terlebar dekat pangkal daun) dan berwarna hijau dengan tepi daun rata dan ujung daun meruncing. Mahkota bunga berwarna putih dengan anter bunga berwarna biru serta kedudukan bunga tegak pada pohon cabai rawit. Warna buah hijau pada saat sebelum matang dan berwarna merah pada saat masak. Memiliki bentuk buah hornshaped (berbentuk tanduk) dengan ujung buah yang tumpul serta memiliki bentuk kaliks enveloping (membungkus). Karakter komponen hasil diantaranya bobot buah per tanaman memiliki nilai rata-rata sebesar 9,47-15,08 g, rata-rata jumlah buah per tanaman sebanyak 125,67-169,67 buah, cabai rawit memiliki panjang buah 0,73-0,82 cm dan buah memiliki diameter 0,36-0,38 cm.
\end{abstract}

\section{Pendahuluan}

Tanaman Cabai rawit (Capsicum frutescens L.) adalah tanaman perdu dengan rasa buah pedas yang disebabkan oleh kandungan capsaicinoids. Secara umum cabai memiliki banyak kandungan gizi dan vitamin, diantaranya kalori, protein, lemak, karbohidrat, kalsium, vitamin A, B1, dan vitamin C (Rukmana, 2002). Sayuran buah ini mempunyai prospek ekonomi yang menguntungkan, digunakan untuk kebutuhan rumah tangga, industri makanan, dan farmasi yang meningkat pesat di Indonesia. Manfaat utama cabai bagi konsumen adalah sebagai bahan penyedap atau bumbu masakan. Selain dapat dikonsumsi dalam bentuk segar, cabai juga dibutuhkan sebagai bahan baku bagi beberapa industri seperti sambal, saus, variasi bumbu, oleoresin, pewarna dan obat-obatan (analgesik) (Hilmayanti $d k k$. 2006).

Cabai rawit asal pulau Timor merupakan plasma nutfah lokal yang biasa disebut juga dengan istilah lombok padi atau kurus, dan dalam bahasa daerah setempat disebut un makaos. Cabai lokal asal pulau Timor memiliki kekhasan baik bentuk dan rasa yaitu berukuran kecil atau mini dengan rasa yang sangat pedas. Umumnya memiliki panjang berkisar antara 1-2 cm.

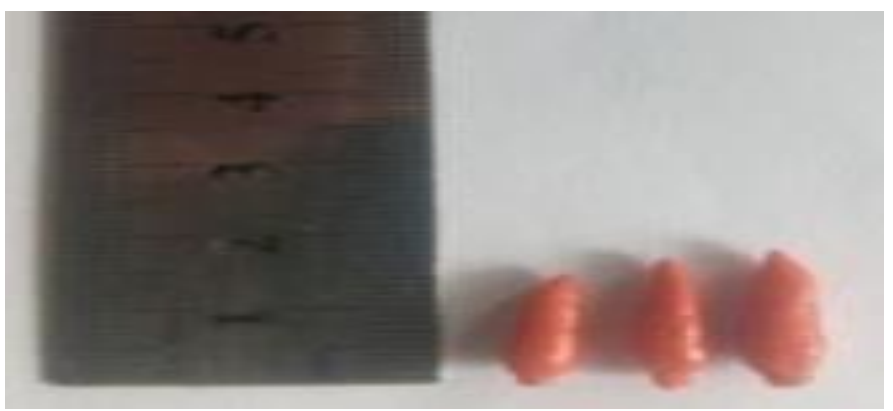

Gambar 1. Cabai Rawit Pulau Timor (un makaos)

Karakterisasi plasma nutfah cabai rawit asal pulau Timor dilakukan untuk mendapatkan deskripsi sifat tanaman dan sebagai bahan working collection sifat tanaman yang akan digunakan sebagai bahan dalam program pemuliaan tanaman cabai rawit. Untuk mengantisipasi erosi gen tanaman cabai rawit dilakukan pelestarian bahan genetik tanaman melalui serangkaian kegiatan berupa eksplorasi karakterisasi dan dokumentasi (Chardha dkk., 1992). Kegiatan ini akan dihasilkan deskripsi tanaman yang penting artinya sebagai pedoman dalam pemberdayaan sumber daya genetik dalam program pemuliaan (Zango $d k k ., 2016)$.

Plasma nutfah adalah substansi sebagai sumber sifat keturunan yang terdapat di dalam setiap kelompok organisme yang dapat dimanfaatkan dan dikembangkan atau dirakit agar tercipta suatu jenis unggul atau kultivar baru (Kusandriyani \& Muharam, 2005). Plasma nutfah banyak dikaji dan dikoleksi dalam rangka meningkatkan produk pertanian dan penyediaan pangan karena plasma nutfah merupakan sumber gen yang berguna bagi perbaikan tanaman. Penelitian plasma nutfah merupakan bagian integral dari pengelolaan plasma nutfah untuk menggali informasi kekayaan sifat genetik dari materi koleksi plasma nutfah, baik untuk tujuan penyediaan tetua persilangan maupun bahan publikasi ilmiah (Kusandriyani \& Luthfy, 2006). Plasma nutfah sebagai bahan pemuliaan dapat dikumpulkan dengan jalan eksplorasi dan introduksi. Plasma nutfah penting dilakukan karakterisasi morfologi untuk diperoleh bahan informasi sebagai langkah awal dalam program pemuliaan tanaman.

Zhongwen (1991), menyatakan bahwa pemuliaan tidak akan dapat memanfaatkan koleksi plasma nutfah tanpa mengetahui terlebih dahulu deskripsi yang jelas dari koleksi tersebut. Karakterisasi bertujuan untuk mengetahui informasi yang terkandung dalam setiap genotipe dari koleksi plasma nutfah yang dimiliki, sehingga langkah yang akan diambil dalam program pemuliaan tanaman cabai rawit akan terarah dan pasti.

Pengakuan terhadap suatu varietas dalam kerangka ketentuan UPOV (International Union for The Protection of New Varieties of Plants) akan memberikan perlindungan legal kepada pemuliaannya, dikenal sebagai hak-hak pemulia tanaman (plant breeder srights). Sesuai dengan perundangan Negara yang menandatangani UPOV seperti Plant Variety Protection Act di Amerika Serikat atau UU Perlindungan varietas tahun 2000 di Indonesia (UPOV, 2006) dan standar yang ditetapkan oleh IPGRI (International Plant Genetic Resources Institute). Plasma nutfah merupakan substansi sebagai sumber sifat keturunan yang terdapat di dalam setiap kelompok organisme yang dapat dimanfaatkan dan kembangkan atau dirakit agar terciptanya jenis unggul atau kultivar. Bertolak dari uraian tersebut maka sangat penting dilakukan karakterisasi terhadap tanaman cabai rawit asal pulau Timor dalam mendukung program pemuliaan. Tujuan dari penelitian ini adalah untuk mendapatkan deskripsi sifat tanaman dan sebagai bahan working collection sifat tanaman yang akan digunakan sebagai bahan dalam program pemuliaan tanaman cabai rawit.

\section{Metode}

\subsection{Waktu dan Tempat}

Lokasi penelitian dilaksanakan di kebun percobaan Fakultas Pertanian, Universitas Timor-Kabupaten Timor Tengah Utara. Waktu pelaksanaan penelitian dari bulan Maret-September 2018

\subsection{Pelaksanaan Penelitian}

1. Eksplorasi Bahan Aksesi

Kegiatan ini dilakukan untuk tujuan mencari informasi dan daerah adaptasi serta mengumpulkan aksesi cabai rawit sebagai bahan koleksi untuk pemuliaan tanaman cabai rawit. Penelitian ini menggunakan benih cabai rawi yang diambil dari Kecamatan Insana-Kabupaten Timor Tengah Utara. Daerah penyebarannya di hutan yang diambil sebagai bahan koleksi pemuliaan tanaman cabai rawit. Setiap nomor aksesi cabai rawit ditanam dalam polybag dengan jumlah aksesi sebanyak 48 tanaman/polybag.

2. Persiapan Media Tanam

Media tanam yang digunakan berupa campuran tanah dan pupuk kandang (dengan perbandingan 1:1). Media ini sebagai tempat tumbuh tanaman dan menyediakan unsur hara bagi tanaman.

3. Persemaian Benih

Persemaian benih dilakukan pada media semai, dengan mencampurkan tanah dan pupuk kandang. Setelah bibit berumur 21 hari atau ditandai dengan 4 5 plumula dapat dipindahkan ke dalam polybag penanaman.

4. Penanaman

Penanaman benih dilakukan pada sore hari dengan menanam 1 bibit cabai rawit dalam 1 polybag. Keseluruhan populasi tanaman berjumlah 48 tanaman.

5. Pemeliharaan

Pemeliharaan menyangkut kegiatan: penyiraman, penyiangan, penyulaman dan pengendalian hama dan penyakit.

6. Pengamatan

Pengamatan dilakukan dengan mengamati karakter morfologi dan komponen hasil

7. Panen

Panen buah dilakukan pada saat buah telah memasuki masak fisiologis yang ditandai dengan perubahan warna buah dari hijau menjadi hijau kemerahan. 


\subsection{Parameter Pengamatan}

Berdasarkan kerangka ketentuan UPOV (2006) akan memberikan perlindungan legal kepada pemuliaan dan standar yang ditetapkan oleh IPGRI 1995 yang meliputi:

1. Tinggi tanaman $(\mathrm{cm})$, diukur dari permukaan tanah sampai pucuk tanaman tertinggi pada panen.

2. Karakter batang:

a. Bentuk batang, diamati pada saat panen

b. Warna batang: hijau, hijau dengan garis ungu, ungu, dan lainnya yang diamati pada saat panen.

c. Diameter batang (mm), diukur pada saat panen.

d. Pemendekan ruas: tidak ada, satu sampai tiga, lebih dari tiga
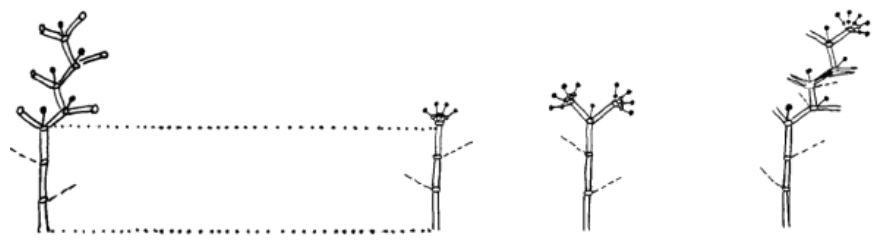

Gambar 2. Pemendekan ruas: a) tidak ada, b) satu sampai tiga, c) lebih dari tiga Sumber : UPOV 2006 dan IPGRI 1995

3. Habitus tanaman: menyamping, kompak, dan tegak, diamati ketika 50\% populasi tanaman telah mempunyai buah masak

(a)
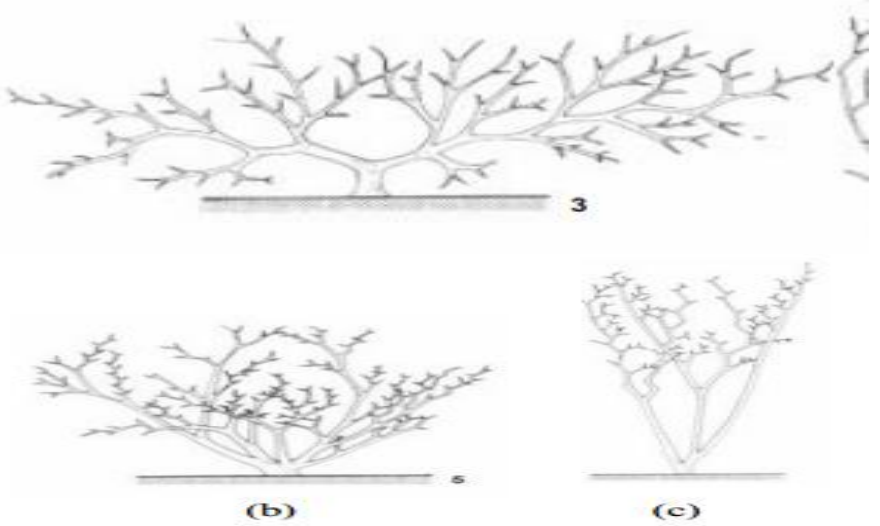

Gambar 3. Habitus tanaman: a) menyamping, b) kompak, c) tegak Sumber: UPOV 2006 dan IPGRI 1995

4. Karakter daun:

a. Bentuk daun, diamati pada saat panen.

b. Warna daun: kuning, hijau muda, hijau, hijau tua, ungu muda, ungu, variegata, dan lainnya yang diamati pada saat panen.

c. Tepi daun: rata, bergerigi, berombak, dan lainnya yang diamati pada saat panen.

d. Ujung daun: meruncing, tumpul, membelah, membuka, dan lainnya yang diamati pada saat panen.

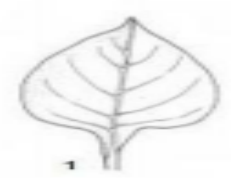

(a)

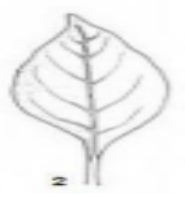

(b)

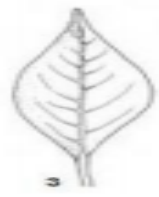

(c)
Gambar 4. Bentuk daun: a) Lanceolate, b) Ovate, c) Broadelliptic Sumber : UPOV 2006 dan IPGRI 1995

5. Karakter bunga dan buah

a. Waktu munculnya bunga, jumlah hari setelah tanam sampai $50 \%$ populasi mempunyai bunga mekar.

b. Warna mahkota bunga: putih, kuning terang, kuning, ungu dengan dasar putih, putih dengan dasar ungu, putih dengan pinggiran ungu, ungu, dan lainnya yang diamati setelah bunga pertama membuka sempurna.

c. Warna anther

d. Kedudukan bunga: tidak tegak, semi tegak, dan tegak.

e. Warna buah sebelum matang: putih kehijauan, kekuningan, hijau, ungu.

f. Warna buah matang: kuning, jingga (oranye), merah, cokelat

g. Bobot buah per tanaman $(\mathrm{g})$

h. Jumlah buah per tanaman (buah).

i. Panjang buah $(\mathrm{cm})$.

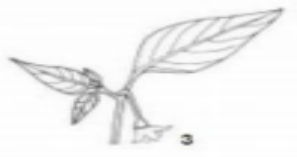

(a)

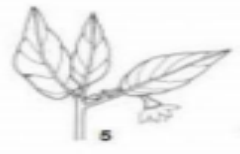

(b)

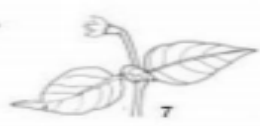

(c)
Gambar 5. Kedudukan bunga: a) tidak tegak, b) semi tegak, c) tegak Sumber : UPOV 2006 dan IPGRI 1995

j. Diameter buah (mm).

k. Bentuk buah: yang diamati pada saat panen.
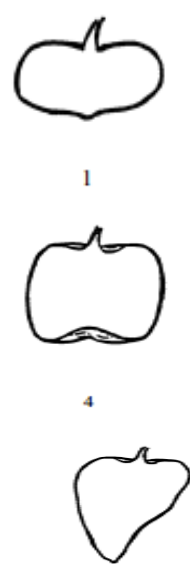

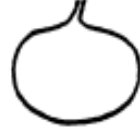

2
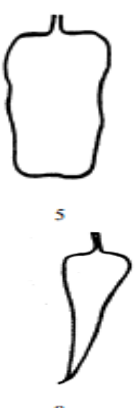
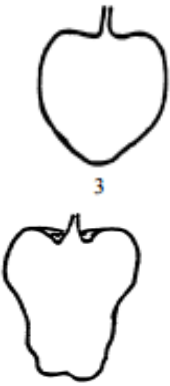

6

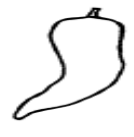

Gambar 6. Bentuk buah: 1) Oblate, 2) Circular (bundar), 3) Cordate (berbentuk hati), 4) Square (kotak), 5) Rectangular (persegi panjang), 6) Trapezoidal (trapesium), 7) Moderately triangular (agak segitiga), 8) Narrowly triangular (sedikit segitiga), 9) Hornshaped (berbentuk tanduk)

Sumber: UPOV 2006 dan IPGRI 1995

6. Bentuk ujung buah: runcing, tumpul, membulat, berlekuk, berlekuk dan meruncing yang diamati pada saat panen.

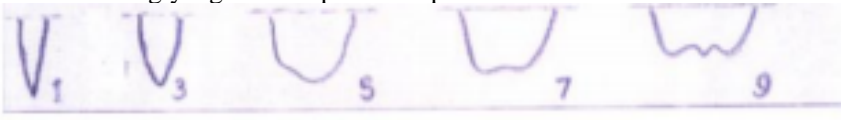

(a)

(b)

(c)

(d)

(e)

Gambar 7. Bentuk ujung buah: a) runcing, b) tumpul, c) membulat, d) berlekuk, e) meruncing UPOV 2006 dan IPGRI 1995

7. Bentuk kaliks (Calyx/daun pelindung/kelopak bunga)

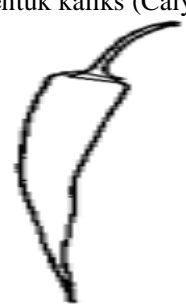

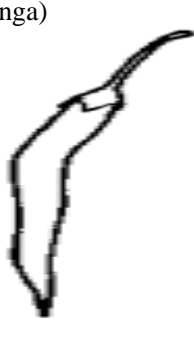

ב
Gambar 8. Bentuk kaliks 1) Tidak membungkus (Non enveloping), 2) Membungkus (Enveloping)

\subsection{Metode Pengambilan Data}

Metode pengambilan data karakterisasi dapat berupa analisis kualitatif dan kuantitatif (komponen hasil) dalam bentuk pengamatan terhadap morfologi tanaman sebagai data informasi karakter penting yang dihasilkan dari kegiatan yang dilakukan di lapangan. berdasarkan kerangka ketentuan UPOV 2006 dan standar yang ditetapkan oleh IPGRI 1995.

\section{Hasil dan Pembahasan}

Karakterisasi morfologi tanaman cabai dilakukan setelah tahap eksplorasi atau pengumpulan genotipe yang nantinya akan dilakukan proses seleksi. Hasi dari karakterisasi ini berupa data morfologi dari suatu genotipe sebagai acuan dalam pelepasan varietas dalam program pemuliaan. Karakter yang diamati berupa karakter-karakter agronomi (karakter kualitatif) dan komponen hasil. Salah satu sasaran pemuliaan cabai diantaranya adalah perbaikan daya hasil dan perbaikan karakter-karakter hortikultura. Pemuliaan pada tanaman cabai 
diarahkan untuk memperoleh cabai unggul. Menurut Syukur $d k k$. (2012) karakter unggul cabai merupakan karakter-karakter yang mendukung hasil tinggi dan kualitas buah prima.

Salah satunya adalah cabai rawit asal Pulau Timor yang dalam bahasa setempat disebut un makaos, un lili, un fua melu atau un ana. Daerah adaptasi awal cabai rawit tumbuh secara liar di hutan, berada di bawah tegakan pohon dan ternaungi serta mampu berkompetisi dengan faktor pertumbuhan seperti air, unsur hara maupun cahaya matahari. Umumnya menunjukkan pertumbuhan vegetasi yang rimbun dengan buah yang berwarna merah, berukuran kecil dan rasanya pedas, tahan terhadap hama dan penyakit. Keistimewaan rasa pedas pada cabai terutama karena kandungan senyawa metabolit sekunder yang terkandung di dalam buah cabai yaitu kandungan capsaicin dan dihidrocapsaicin. Capsaicin terdapat pada plasenta buah, tempat melekatnya biji. Umumnya tingkat kepedasan senyawa Capsaicin berbeda-beda tergantung spesies cabai. Capsicum frustescens (cabai rawit) memiliki buah yang masih muda berwarna putih, kuning, atau hijau. Bunganya berwarna putih kehijauan. Pada umumnya, dalam satu ruas terdapat satu kuntum bunga, tetapi kadang-kadang lebih dari satu. Tangkai bunga tegak saat anthesis, tetapi bunganya merunduk, sedangkan tangkai daun pendek. Daging buah umumnya lunak, dengan kapsaisin yang kadarnya tinggi, sehingga rasa buah pedas. Umumnya cabai rawit dipanen ketika buah masih muda, berwarna hijau, putih, atau kuning. Umur panennya lebih panjang daripada $C$. апnиит (Kusandriani \& Muharam, 2005).

Pengamatan karakterisasi cabai rawit pulau Timor dalam penelitian ini dilakukan untuk mengamati karakter morfologi (kualitas) dan komponen hasil yang nantinya digunakan sebagai acuan dalam pengembangan cabai rawit lokal asal pulau Timor, sehingga dapat dibudidayakan secara optimal oleh petani. Penampilan suatu tanaman ditentukan oleh faktor genetik, lingkungan dan interaksi antara keduanya. Hal ini mempengaruhi karakter kualitatif dan kuantitatif tanaman. Faktor genetik diwariskan dari tetua kepada turunannya, sedangkan faktor lingkungan bisa dimanipulasi agar tanaman dapat tumbuh seoptimal mungkin (Syukur $d k k$., 2012). Karakter-karakter tertentu pada tanaman seperti warna bunga, bentuk polong, dan warna polong, dikendalikan oleh gen sederhana (satu atau dua gen) dan tidak atau sedikit sekali dipengaruhi oleh lingkungan. Karakter ini disebut karakter kualitatif. Karakter-karakter kualitatif yang dikendalikan oleh gen mayor dan tidak dipengaruhi perubahan lingkungan yang pada umumnya memiliki nilai heritabilitas tinggi, serta peluang ditemukannya pada turunan bersegregasi cukup besar. Karakter kualitatif adalah karakter yang dikendalikan oleh gen sederhana (satu atau dua gen) dan tidak atau sedikit sekali dipengaruhi oleh lingkungan (Syukur $d k k ., 2012$ ).

\subsection{Morfologi Tanaman Cabai Rawit Un Makaos}

Karakter kualitatif adalah karakter yang dikendalikan oleh gen sederhana (satu atau dua gen) dan tidak atau sedikit sekali dipengaruhi oleh lingkungan (Syukur $d k k ., 2012$ ). Batang yang memiliki nama latin caulis, merupakan salah satu organ tubuh tumbuhan yang tergolong cormophyta (tumbuhan yang dengan nyata memperlihatkan diferensiasi dalam tiga bagian pokok yaitu akar, batang, dan daun). Batang merupakan bagian tumbuhan yang amat penting, dan mengingat tempat serta kedudukan batang bagi tubuh tumbuhan, batang dapat disamakan dengan sumbu tubuh tumbuhan. Pada umumnya, batang merupakan tempat tumbuhnya organ tubuh tumbuhan yang lain seperti tangkai, buah, daun dan bunga. Bentuk batang berkaitan dengan perubahan diameter batang karena perubahan tinggi (Yulianita, 2012).

Hasil karakterisasi morfologi menunjukkan bahwa habitus tanaman cabai rawit ini tergolong kompak batang cabai rawit memiliki bentuk silindris. Bentuk 4 . silindris ditandai dengan bagian tengah pohon yang mempunyai diameter sama antara bagian pangkal serta ujung (Yulianita, 2012). Batang cabai umumnya berwarna hijau sampai hijau keunguan bila batangnya semakin tua. Pemendekan ruasnya lebih dari tiga.

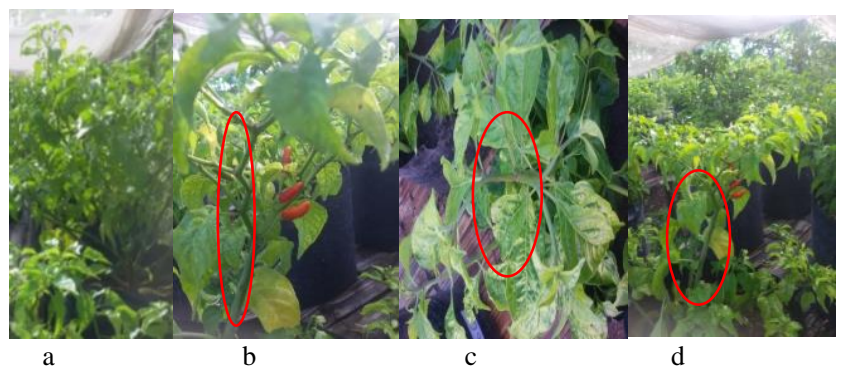

Gambar 9. a) Habitus tanaman kompak, b) Pemendekan ruas lebih dari Tiga, 3) Batang berwarna hijau, d) Batang berbentuk silindris

Daun cabai rawit un makaos umumnya berwarna hijau karena terdapat kandungan klorofil. Klorofil adalah pigmen yang berperan penting dalam proses fotosintesis. Klorofil merupakan zat hijau daun yang terdapat pada semua tumbuhan hijau yang berfotosintesis. Sel-sel mesofil yang terdapat di daun banyak mengandung kloroplas. Di dalam kloroplas terdapat klorofil (zat hijau daun) (Iriyani \& Nugrahani, 2014). Secara genetis daun un makaos memiliki tepi daun yang rata, ujung daunnya meruncing dan bentuk daunnya ovate.
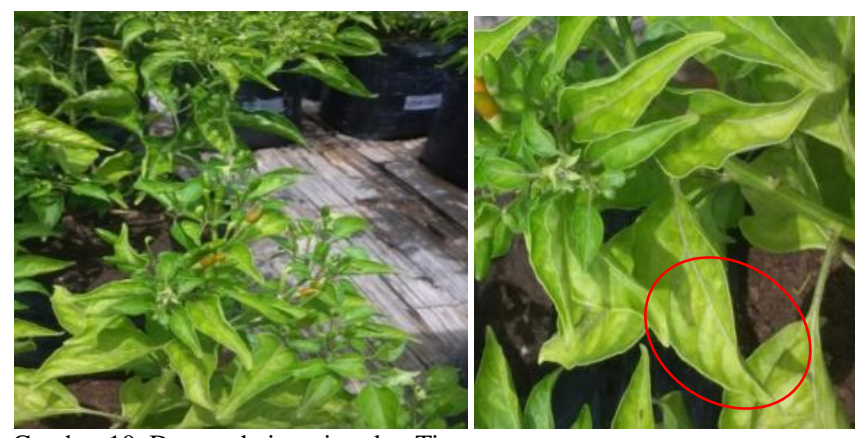

Gambar 10. Daun cabai rawit pulau Timor

Mahkota bunga yang dimiliki berwarna putih dengan kedudukan bunga tegak. Warna buah sebelum matang pada cabai un makaos adalah hijau dan warna buah matang adalah merah. Perbedaan warna buah ini berkaitan dengan erat dengan pigmen antosianin dan karotenoid.
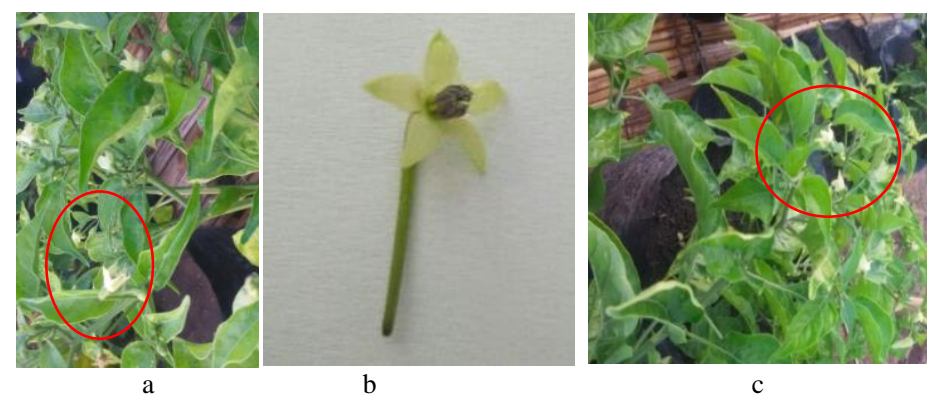

Gambar 11. a) Warna bunga putih, b) Warna anther biru, c) Kedudukan bunga tegak

Warna pada buah matang merupakan akibat dari reduksi klorofil, pigmentasi antosianin dan akumulasi pigmen karotenoid. Capsanthin dan Capsorubin adalah pigmen terbanyak pada buah matang yang berwarna merah (Stommel \& Albrecht (2012). Bentuk buah saat panen berbentuk Hornshaped atau berbentuk tanduk, ujung buahnya berbentuk tumpul, dan bentuk kaliks cabai rawit yaitu membungkus atau enveloping (UPOV, 2006).
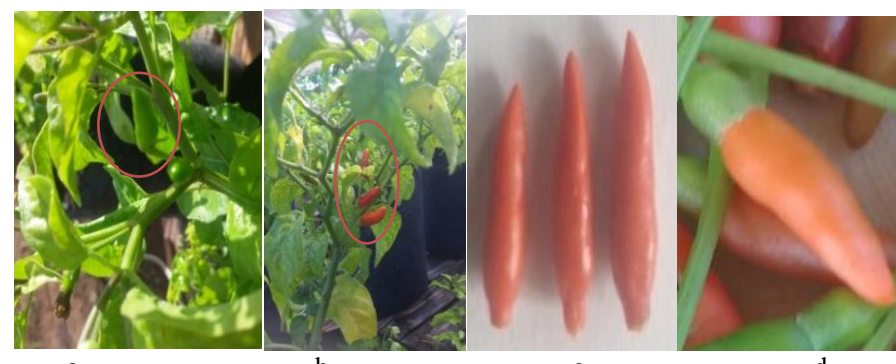

a

Gambar 12. a) Warna buah hijau, b) Warna buah merah, c) Bentuk buah hornshaped (berbentuk tanduk) dan ujung buah tumpul, d) Kaliks berbentuk enveloping (membungkus)

Hasil penelitian Undang dkk., (2015) pada genotip IPBC295 yang teridentifikasi sebagai cabai rawit spesies $C$. frutescens menunjukkan karakter warna mahkota (corolla) hijau keputihan, warna anter biru, warna buah muda hijau, putih, dan putih kehijauan, tangkai buah mengecil atau menyempit pada bagian pangkal buah, bentuk daun deltoid ( Undang dkk., 2015).

\subsection{Karakter Komponen Hasil}

Banyak karakter yang mempunyai nilai ekonomi dan agronomi sangat penting seperti daya hasil, ukuran tanaman, ketahanan kekeringan, ketahanan rebah, dan kualitas hasil umumnya dipengaruhi oleh banyak gen serta dipengaruhi lingkungan. Karakter seperti ini disebut karakter kuantitatif (Syukur $d k k ., 2012$ ). Tanaman cabai un makaos yang daerah asal tumbuhnya di hutan dan merupakan plasma nutfah di pulau Timor, merupakan salah satu materi genetik dalam program pemuliaan tanaman, sehingga perlu dilakukan budidaya secara optimal agar dapat dikembangkan oleh petani. Berdasarkan eksplorasi benih, telah dilakukan penelitian untuk mengukur produktivitas cabai rawit bila dilakukan budidaya dengan menanamnya pada lahan terbuka (lahan budidaya). Hasilnya akan digunakan dasar upaya perbaikan pemuliaan tanaman cabai.

Karakter kuantitatif adalah karakter yang pada umumnya dipengaruhi oleh banyak gen serta dipengaruhi lingkungan (Syukur $d k k$., 2012). Pengukuran terhadap karakter komponen hasil yang diperoleh setelah dilakukan budidaya cabai rawit terhadap 48 sampel tanaman. Perlakukan yang diberikan dengan melakukan pemupukan guano pada tanaman sebagai sumber nutrisi. Dengan 
melakukan budidaya secara optimal dapat diperoleh produktivitas un makaos, selain itu sebagai sumber penyediaan materi genetik dalam program pemuliaan tanaman un makaos asal pulau Timor.

Tabel 1. Karakter Komponen Hasil

\begin{tabular}{lr}
\multicolumn{1}{c}{ Karakter Komponen Hasil } & \multicolumn{1}{c}{ Ukuran } \\
\hline Bobot buah per tanaman (g) & $9,47-15,08$ \\
Jumlah buah per tanaman (buah) & $125,67-169,67$ \\
Panjang buah (cm) & $0,73-0,82$ \\
Diameter buah (cm) & $0,36-0,38$ \\
\hline
\end{tabular}

\section{Simpulan}

Karakterisasi morfologi dan komponen hasil un makaos meliputi 1) habitus tanaman dengan percabangan yang kompak, bentuk batang silindris, pemendekan ruas lebih dari tiga dan memiliki batang berwarna hijau; 2) daun cabai berbentuk ovate dan berwarna hijau dengan tepi daun rata dan ujung daun meruncing; 3) memiliki mahkota bunga berwarna putih dengan anter bunga berwarna biru serta kedudukan bunga tegak pada pohon cabai rawit; 4) warna buah hijau pada saat sebelum matang dan berwarna merah pada saat masak. Memiliki bentuk buah hornshaped (berbentuk tanduk) dengan ujung buah yang tumpul serta memiliki bentuk kaliks enveloping (membungkus); dan 5) karakter komponen hasil memiliki nilai rata-rata yang terukur diantaranya bobot buah per tanaman sebesar 9,47-15,08 g, rata-rata jumlah buah per tanaman sebanyak $125,67-169,67$ buah, cabai rawit memiliki panjang buah $0,73-0,82 \mathrm{~cm}$ dan buah memiliki diameter $0,36-0,38 \mathrm{~cm}$.

\section{Pustaka}

Chardha, M.L., A.M.K. Amzad Hotsain\& S.M. Monowar. 1992. Germplasm Collection, Evaluation, Documentation and Conservation. Taiwan: Asian Vegetable Research and Development Center. Shan Hua.

Hilmayanti, I., W. Dewi, Murdaningsih, M. Rahardja, N. Rostini \&R. Setiamihardja. 2006. Pewarisan Karakter Umur Berbunga dan Ukuran Buah Cabai Merah (Capsicum annuum L.). Zuriat 17(1):86-93.

Iriyani. D \& A. Nugrahani. 2014. Kandungan Klorofil, Karetonoid dan Vitamin C Beberapa Jenis Sayuran Daun pada Pertanian Peniurban di Kota Surabaya. Jurnal Matematika, Sain, dan Teknologi. 15(2).

IPGRI (International Plant Genetic Resources Institute). 1995. Descriptorsfor Capsicum (Capsicum spp.). Roma. ITA: International Plant Genetic Resources Institute.

Kusandriyani Y \& Muharam A. 2005. Produksi Benih Cabai. Bandung: Balai Penelitian Tanaman Sayuran.

Kusandriyani, Y \& Luthfy.2006. Karakterisasi Plasma Nutfah Kangkung. Buletin Plasma Nutfah. Vol 12 No 1 Tahun 2006. Badan Penelitian dan Pengembangan Pertanian. Departemen Pertanian.

Rukmana, R. 2002. Usaha Tani cabai Hibrida Sistem Mulsa Plastik. Yogyakarta: Kanisius.

Stommel J.R \& Albrecht E. 2012. Genetics. p. 29-56. In: Russo V.M. (Eds) Peppers: Botany. London: UK: Production and Uses. CAB International.

Syukur M., Sujiprihati S\& Yunianti R. 2012. Teknik Pemuliaan Tanaman. Bogor: Penebar Swadaya.

Undang, M. Syukur\&Sobir. 2015. Identifikasi Spesies Cabai Rawit (Capsicum spp.) Berdasarkan Daya Silang dan Karakter Morfologi. J. Agron. Indonesia 43(2): 118 - 125.

UPOV (International Union for The Protection of New Varieties of Plants). 2006. Geneva. Tersedia di www.upov. Int. [Diunduh 12 April 2017].

Yulianita N. 2012. Morfologi Tumbuhan. Yogyakarta: Kanisius.

Zango O., Hervé Rey., Yacoubou Bakasso., René Lecoustre., Frédérique Aberlenc \& Jean-Christophe Pintaud.2016. Local Practices and Knowledge Associated with Date Palm Cultivation in Southeastern Niger. Agricultural Sciences. 7(9).

Zhongwen. 1991. Approachto Germplasm Characterzationand Evaluation Procedingof the ISO/IBFC. China. Training Courseon General Strategi in Jule/Kenaf Breeding. 